pag

Business School

WORKING PAPER SERIES

\begin{tabular}{l|l} 
Working Paper & $\begin{array}{l}\text { Entrepreneurial intention and career } \\
\text { choices: The role of volition }\end{array}$ \\
$2014-167$ & $\begin{array}{l}\text { S. Nyock Ilouga } \\
\text { A.C. Mouloungui } \\
\text { J.-M. Sahut }\end{array}$
\end{tabular}

http://www.ipag.fr/fr/accueil/la-recherche/publications-WP.html

IPAG Business School

184, Boulevard Saint-Germain

75006 Paris

France 


\title{
ENTREPRENEURIAL INTENTION AND CAREER CHOICES : THE ROLE OF VOLITION
}

\author{
S. Nyock Ilouga \\ FBS Campus d'Amiens - Université Libre de Bruxelles \\ 18, place Saint Michel - 80038 Amiens Cedex 1 France \\ A.C. Mouloungui \\ Université Lille 3 \\ Domaine Universitaire du Pont de Bois BP 60149 \\ 59653 Villeneuve d'ascq Cedex, France \\ J.-M. Sahut \\ IPAG Business School, Paris \\ 184 Boulevard Saint-Germain 75006 Paris \\ jmsahut@gmail.com
}

\begin{abstract}
Developing entrepreneurship among students and helping them to build their career plans and improving their employability is the core of public policy in a lot of countries in Europe (Branchet et al., 2011). Following some empirical researches (Boissin et al., 2009), we do know some predictive factors for the emergence of an entrepreneurial project. But another question remains largely unexplored: What are the psychological mechanisms that may interplay in entrepreneurial intention and career choices?

Our research aims to demonstrate that entrepreneurship is an objective which relies entirely on willingness, and therefore, it is much more dependent on interpersonal features than on economic and environmental constraints. In particular, we wish to highlight the personal dynamics in shaping, maturing and implementing a choice of entrepreneurial career in order to extract volitional characteristics of this career choice. The hypotheses are tested using data from interviews conducted with French students in business schools, engineering schools and universities. Our dynamic approach to study the psychosocial processes involved in the definition of an entrepreneurial career helps understand the interest of young people in the entrepreneurial process. This research has demonstrated that volition has a key role in binding an individual commitment to an ambitious career objective.
\end{abstract}

Keywords: entrepreneurship, career, volition, entrepreneurial intention, entrepreneurial project, theory of planned behavior

JEL Classification: L26, M53, J24, H52 


\section{INTRODUCTION}

France is among the countries where entrepreneurship is not frequently considered as a career option. This has been confirmed for several years by international studies from the Global Entrepreneurship Monitor, which reveals an established fact: an entrepreneur is someone whose job is an unusual career in France. This is particularly true for young graduates of higher education. Among all the start-ups recorded in 2011, only $12 \%$ were, actually, from young graduates of higher education (INSEE Première, 2012).

Today, France and Europe have many obligations and challenges to develop the entrepreneurial spirit among students. Over the past decade, research and training opportunities in entrepreneurship increased strongly in service education. Encouraging universities, high schools, incubators and entrepreneurial networks to coordinate and develop common tools to reach the students is the core of public policy in developing entrepreneurship within this particular population as well as helping them to build their career plans and improving their employability (Branchet et al., 2011). A choice of career becomes especially crucial because of the current economic difficulties. The latter do not facilitate vocations because uncertainty about the future and the prospect of unemployment reinforce the indecision on the career choices for many young people. Under these conditions, entrepreneurship could appear as an attractive alternative to circumvent unemployment and offer young people the opportunity to imprint an original brand into reality while taking into account the social limitations.

Relying on the knowledge from the field of educational and vocational orientation, it appears that the decision is to choose an option among a range of possibilities, being confronted to the environment, equipped with our skills and haunted by our aspirations. The decision appears to be one of the necessary steps to consider in the construction of one's career (Fraccaroli and Vitali, 2001). This construction is not linear given the progression of skills and grades, but rather a sequence of future career paths. Among the options, there may be a hierarchy of priorities for the goals to pursue. Therefore, if the difficulties for the individual, namely internal and external ones hinder the achievement of the higher purpose, the next goal may become a priority because of its rationality.

Theoretical reflections and empirical research from school psychologists and career advisors revealed that the choice of an occupation or and educational training is a socialization process, in which many factors and various agents of influence like family, friends, and institutions are involved. They also identified the elements to build and monitor an individual's career: attitude (Battistelli, 2001), interests (Holland, 1973), inclination (Cromie, 2000) and intention (Ajzen and Fishbein, 1975). Overall, the research on entrepreneurial career focuses on the distinction between entrepreneurs and non-entrepreneurs to determine the psychological characteristics of entrepreneurs and explain the interest of certain persons for an entrepreneurial career. More specifically, researchers have focused on factors that may explain this choice, relying in particular on opinions, perceptions of risks and rewards, selfefficiency, parental support, motivation, values, the environment and attitudes towards selfemployment and entrepreneurship (Fraccaroli and Vitali, 2001; Battistelli, 2006; Odoardi, 2008; Gasse, 2008; Boissin et al., 2009). Meanwhile, management researchers were more interested in understanding the process of entrepreneurship (Krueger, 1993), mainly from models of intent, such as the theory of planned behavior (Ajzen, 2002).

Following these results, we do know some predictive factors for the emergence of an entrepreneurial project. But another question remains largely unexplored: What are the psychological mechanisms that may interplay in entrepreneurial intention and career choices? 
Indeed, it is common to see highly motivated people with a strong intention to perform an action, being unable to perform the necessary actions to realize this intention. For some, this incapacity is the result of the instability of their intentions regarding time (Moreau and Raveleau, 2006). For others, the inherent difficulties in achieving such a goal, despite a challenging environment and a high level of motivation, evokes a lack of individual characteristics, which has long been considered as a virtue by philosophers and as a "faculty": willingness or volition by psychologists (Broonen, 2007).

Obviously, the problem with studying willingness is its scientific legitimacy. Indeed, all scientific literature in psychology was dominated by a complete ignorance of volition in the study of human behavior, but this has recently changed. However, this philosophy is not widely shared by German psychologists, including Gollwitzer and his peers (Gollwitzer and Heckhausen, 1987; Gollwitzer, 1993; Oettinger et al., 2000). More recently, it has been emphasized by Belgian psychologists Broonen $(2007,2010)$ for whom volition is the process that determines the transition from intention to action.

As a matter of fact, we want to propose a model that reconciles some theories that are largely validated by the scientific community, which is the theory of planned behavior and the theory of reasoned action and another less-used theory i.e. the theory of volition, in order to examine the relationship between environmental factors and individual features associated with volition in the genesis and implementation of an entrepreneurial intention.

Our approach aims to demonstrate that entrepreneurship is an objective which relies entirely on willingness, and therefore, it is much more dependent on interpersonal features than on economic and environmental constraints. In particular, we wish to highlight the personal dynamics in shaping, maturing and implementing a choice of entrepreneurial career in order to extract volitional characteristics of this career choice.

The hypotheses are tested using data from interviews conducted with French students in business schools, engineering schools and universities. The rest of the paper is structured as follows. We first present the corpus of literature to which this study contributes. We then present our hypotheses and methodology, followed by our empirical analysis. Finally, we discuss our findings and the implications for different stakeholders.

\section{LITERATURE REVIEW}

The career plan is defined as a gradual construction that is rooted in the past, embracing the present and going beyond it to provide a meaning for the future, and allowing for the development of the young person's identity (Charpentier, Collin and Scheurer, 1993), is according to Forner (1999), an aid to academic success. This definition is not consensual. Systematic observations showed that the probability of academic success is much better for students who have a project as opposed to those whose decision is subject to other factors such as parental injunction (Broonen, 2007) or the criteria established by supporting institutions. However, other studies find no difference between students who are decided or undecided about their future (Ashby, Wall, and Osipow, 1966). Others have even revealed differences benefiting the undecided (Forner and Autret, 2000).

We know that indecision in the choice of a training or work is an indicator of a lack of purpose (Forner, 1999). Crites (1969) has linked indecision to the inability to make a choice in questioning people's future intentions. These intentions, that is to say orientation or insertion, are constructed on the basis of information on persons or professions. When information is insufficient, it can lead to a state of indecision (Campbell and Cellini, 1981). Generally, including Ajzen and Fishbein (1980), Gollwitzer (1993) and Kuhl (1985), the 
probability that an individual moves into entrepreneurship depends on a number of factors including personality, environmental opportunities, social skills and aspirations. In this respect, vocational decision-making is rather the result of the capacity assessment to carry out the project and to master the environment. However, the realization of one's project will depend not only on the professional objectives and personal success, but also and especially on one's perceived and real skills, volitional abilities, and orientation towards action. In the theory of planned behavior (TCP, Ajzen, and Madden, 1986), the intention is predicted by attitudes towards the behavior, perceived behavioral control and the subjective norm. The individual will only adopt a certain behavior over which he has some level of control, which he believes he is able to complete successfully and that gives him real pleasure.

This ability to control the behavior recalls the notion of action control issued by Kuhl (1985). The action control is the self-regulatory mechanism that mediates between intention and action. Kuhl (1982) hypothesized that individuals differ in their willingness to control their actions, i.e. oriented state versus orientation towards action, but also on the proportion of intentions turned into behavior. In this way, the orientation towards action refers to a person who generally tends to approach things proactively while those "state-oriented" persons reflect the inertia action. Investigations conducted in the control action theory and its ability to predict the action in various fields have been relatively successful. A study by Bagozzi et al. (1992) on the intention to use the coupons and use them effectively in a supermarket showed that orientation towards action increases the relative importance of attitudes, but lessens the impact of subjective norms on intention. Thus, attitudes towards behavior are more important in the formation of intentions in action-oriented people than for "oriented state" people and vice versa. Although these researchers have used the theory of reasoned action and not the TCP (Hale et al., 2003), it appears necessary to integrate volitional skills of self-regulation in the TCP, as the behavioral control structure is a main part in volitional models.

For a long time, volition has been neglected in psychology. However, with the advent of behaviorism, it has become an important feature in the field of training and orientation. Indeed, the motivational processes account for the decision to act, but they do not explain how the individual protects his intention from potential detractors and implements necessary actions. It is at this level that the concept of volition is so important, especially for activities where the difference between the formulation of the objective and its implementation requires a long-term work, such as entrepreneurship. Defined as the sum of mental events or activities through which an agent consciously and actively exercises its potential agent to voluntarily direct his or her thoughts and action (Zhu, 2004), volition is only possible because of the construction of an object's representation, knowledge and inference. The implementation of this volition results in a succession of phases that characterize the action phase's model of Gollwitzer (1996):

- Pre-decisional phase: in the process of choosing a type of action, deciding for a behavior is a momentary "mental action" that is resolved in the formation of an intention to have the behavior (Mele, 2000), depending on the importance of its desirability and feasibility and then, transforms it into a target - "goal intention" leading the individual to be committed to the implementation of specific actions to achieve the pursued objective.

- The pre-action phase has a specificity regarding the activation of volitional control processes, determining the implementation of the objective. These processes are designed to protect the goal intention of "distractors" through self-defensive mechanisms and activate the cognitive means to achieve it. To translate this transition from a state of deliberation to a sense of commitment, Gollwitzer and Heckhausen (1987) are using the metaphor of crossing the Rubicon. It clarifies the transition from a motivational -predecision phase to a volitional phase -pre-action. As previously suggested the decision puts 
an end to the debate and confines the individual to a mental state of execution implemental mindsets- for the goal intention.

- The third phase is the so-called action phase in which the individual realizes his goal concretely and consciously. The skills for actions development, namely orientation towards action, concentration and proactivity intervene in this phase. The level of volitional strength depends on the perceived feasibility and the desirability of the objective, before choosing one. However, this strength may vary depending on the experience of the individual. If the person ignores or is not sensitive to situations favorable to the execution of the behavior, volitional strength may decrease over time. On the other hand, it may increase either unexpectedly or when the person encounters obstacles. Once the actions are taken, the person goes to the fourth phase called postaction.

- Finally, the post-action phase consists in evaluating the degree of achievement and interest to continue its action. At this point, two possibilities may arise: to make adjustments or abandon the goal. The person can improve his or her chances for success by adding new intentions or neglecting the consequences of the goal. If no measures are taken, or if all efforts fail, the goal intention may remain at a cognitive stage transforming the individual into a procrastinator (Emmons and Ferrari, 1995).

In addition, it is important to note that the distinction between motivation and volition is still very dimly shaped because the literature on motivation includes volition and vice versa (Forstmeier and Rüddel, 2008). A close examination of the Rubicon model of Gollwitzer (1996) reveals a distinction between volition and motivation, which can be expressed in terms of degree. First motivation emerges, which helps people to choose and set a goal to pursue. Second, volition is triggered, which pushes the individual to progress towards his or her goal. Therefore, the intention can be found in the interaction between motivation and volition. For Corno (2004), volition controls intentions and impulses so that the intended action is achieved regardless of the difficulties and obstacles. Volitional processes protect the intention from actions in competition with other potential distractions. Thus, our point of view is identical to the one of Kuhl (1985) and Corno (2004) that is to say, motivation may lead individuals to initiate actions, while volition leads them to continue the action track they seek to achieve while protecting it from distractors.

In the present work, we refer to volition as the expression of volitional capacity. We postulate that when the student or budding entrepreneur is in a volitional state of mind, he or she begins by focusing on how to proceed to achieve the desired goal. In line with the work of Corno and Kanfer (1993), Kuhl (1985) and Gollwitzer (1993), we conceptualize motivation and volition as distinct concepts, but they are interactive.

\section{HYPOTHESES AND METHODOLOGY}

\subsection{Research hypotheses}

Our research is based on the theoretical models of planned behavior and reasoned action, which explains entrepreneurial behavior through an intention to perform the behavior. Among these models, those who integrate, even partially, volitional and motivational factors seem most likely to account for the determinants of intention depending on the implementation (Hale et al., 2003). Indeed, one cannot simply consider the background of intention in terms of motivation because an individual, being discomforted by the pursuit of his or her purpose or professional project, or even in setting it, must use his or her volitional resources to achieve it. 
The literature on intention (Ajzen and Fishbein, 1980; Ajzen, 2002) reveals that the intention is determined by one's attitude towards behavior, the subjective norm and the behavioral control. In addition, further research on entrepreneurial intention have shown that the construction of entrepreneurship seems to originate from the opinions on entrepreneurship and entrepreneurs, motivation (Battistelli, 2001), self-efficiency (Boyd and Vozikis 1994) and expectations (Battistelli et al., 2003). Even though there is no evidence of a direct relationship between intentions and certain career choices, we can assume that the choice of an occupation depends on the behavioral intention. This intention can be acquired from both personal and social characteristics.

Considering that the idea of devising an entrepreneurial project is a long process that requires an individual commitment and a particular persistence in the pursuit of the goal in spite of some obstacles as well as mobilization of the volitional skills, we suggest the following two hypotheses:

(H1) Students wishing to start-up a business express a higher degree of self-regulation than those who wish to have a paid job.

(H2) Volitional skills, and in particular self-regulation, broadcast the impacts of views on entrepreneurial intention.

We made used a quantitative approach through a structured questionnaire involving a large number of tools based on a comparison of attractions for entrepreneurial careers in opposition to employee careers.

\subsection{MEASUREMENT OF VARIABLES}

\subsubsection{Future intentions}

People were asked about the interest they perceive in a career in public, private, and independent sectors. We used the scale developed by Battistelli (2001), translated into French by Lemoine and Nettersheim (2008), and which is made up of two dimensions: the level of definition of the professional project and the choice of a professional sector for the future. The level of definition of the project has eight items, like "I have no clear idea about my future". The choice of the professional sector has ten items: four items for the interest in careers in the public and / or private, such as "I intend to work in the private sector" and six items for the interest in entrepreneurial career like "My career goal is to become an entrepreneur" - Liñán and Chen's scale (2009). In the same way as professional aspirations, we asked participants to comment on their intended project training, such as "I intend after my Bachelor's Degree, to go to specialized courses, to undertake an optional internship, a Doctorate, or a Master's Degree". It appears that the higher the score on this scale, the more accurate the project is.

\subsubsection{Opinions}

The used scale is the short version (Battistelli and Nyock, 2008) of the original scale developed by Battistelli (2001). This new version includes eighteen items distributed in five dimensions. The Benefactor dimension contains five items e.g. "the entrepreneur provides economic welfare to society". The Commitment and capacity dimension has four items e.g. "an entrepreneur must have many abilities to succeed". There are three items that measure the Exploitative dimension. For instance, "to achieve the greatest benefits, the entrepreneur is willing to do anything". The Positive opportunism dimension has three items, for example, "A successful entrepreneur must find good opportunities". Finally, three items measure the 
Sacrifice dimension such as "the entrepreneur takes risks for the development of the community".

\subsubsection{Volitional skills}

Following the work of Kuhl (2000), we focus our study on the volitional skills of selfregulation. This skills assess the capacity of the individual to use his psychological functions including motivation, determination and strength in the pursuit of the goal, and personal initiative too. Then, self-regulation is decomposed in self-determination, self-motivation, and resistance to uncertainty about the future. "Self-determination" refers to one's ability to confidently present his or her goals and ambitions as well as how to implement them successfully. "Self-motivation" translates the ability to maintain a high level of motivation regardless of the context. "Resistance to uncertainty" refers to the ability to regulate one's internal level of tension to calm down when he or she feels plagued by negative emotions.

There are several such measures of these dimensions in the literature, but there is a consensus over the questionnaire developed by Fuhrmann and Kuhl (1998): " the Volitional Questionnaire Component" (VCQ-3). We thus translated the scale into French. The scale is constructed on the basis of the action control theory (Beckhmann and Kuhl, 1985).

Three items were used to measure the "self-determination" dimension: e.g. "Most of the time, I realize the goals I set for myself". Two items assess "self-motivation", like "I know exactly how to motivate myself when my enthusiasm diminishes", and two others items evaluate "resistance to uncertainty". In addition, the "personal initiative" scale used is the one developed by Battistelli (2001). It has eight items with five possible answers, such as "I use every opportunity to achieve my goals". It evaluates the behavior of the individual using an active and spontaneous approach in relationship with the goals and the action. All these dimensions are measured using a Likert scale with four points.

\section{3. SAMPLE AND DATA COLLECTION}

This study focuses on French students in business schools, schools of engineering and universities. Our choice concerns institutions having approximately the same characteristics: public or affiliated, admitted or selected student on the basis of an entrance exam or after obtaining a Bachelor's Degree, an available career guidance service and realizing the existence of entrepreneurship in the curriculum. These criteria, as well as the accessibility of schools led us to work with two business schools; the Amiens School of Management (ESC Amiens), and the Institute of Business Administration of Grenoble (IAE Grenoble), the Schools of Electrical and Electronics Engineers of Paris and Amiens (ESIEE), the University of Lille 3 and the University of Montpellier 3. All these institutions are located in urban areas. All the data have been collected between September 2010 and May 2011, using a structured questionnaire consisting of the scales explained in the previous paragraph. The mode of gathering information was self-administration assisted by a teacher or by ourselves, which we felt was the most appropriate informative mode for students to answer, especially in terms of rates and user-friendliness. 


\section{RESUlTS}

The persons involved in this study are students from French schools of management, engineering schools, and universities. The sample consisted of 1630 subjects of whom $58.9 \%$ are female and $41.1 \%$ are male. We observe that girls have especially benefited from the democratization of higher education that France experienced starting from the mid-twentieth century. Since the 1970s, girls have exceeded boys in terms of academic success and headcount. This trend is thriving and it is definitely expected to lead to a higher rate of girls compared to that of boys. The respondents were 17 to 29 year-old with an average age of 20.02. They show some level of knowledge about entrepreneurship. Indeed, $22.69 \%$ of them know at least one entrepreneur among the members of their families and $18.40 \%$ know one among friends. Out of our 1630 respondents, 1010 were willing to give us information about the entrepreneurial activity of their parents. In fact, $4.29 \%$ have a parent who has a trade company and $3.68 \%$ have a parent who works in agriculture. $75 \%$ of the respondents have already had a work experience in catering, sales or entertainment, especially as a seasonal employee in summer. These account for $40 \%$.

\subsection{Constructing future intentions among students}

Career choices refer to the career intentions of students: those intentions can be either for an entrepreneurship or a paid occupation. Our results show that $26.99 \%$ of the surveyed students have a structured and a final career scheme, among them 240 girls and 200 boys. However, $16.56 \%$ are yet undecided, they do not have clear ideas about their future, and therefore, they are yet unable to envisage a career plan. Finally, $56.44 \%$ have no specific project at all.

Given the uneven distribution in numbers between girls and boys in our sample, we wanted to test the null hypothesis of proportional formulation of professional projects based on gender. This assumption is founded on the idea that the courses and educational experiences are often gendered. In addition, the orientation of boys and girls does commonly reflect stereotypes and prejudices that limit their course. The results of Pearson's Chi-squared show that the two variables are independent. In other words, the formulation of professional projects does not follow the distribution of the workforce by gender.

Table 1: Distribution of the sample by gender

\begin{tabular}{|l|l|c|c|l|}
\hline $\begin{array}{l}\text { Frequency Distribution by Gender } \\
\text { Numbers > 10 Highlighted }\end{array}$ & $\begin{array}{l}\text { SC-PROF R (PS) } \\
\text { Structured }\end{array}$ & $\begin{array}{l}\text { SC-PROF R (PP) } \\
\text { None }\end{array}$ & $\begin{array}{l}\text { SC-PROF R (PC) } \\
\text { Constructing }\end{array}$ & $\begin{array}{l}\text { Total } \\
\text { per line }\end{array}$ \\
\cline { 2 - 5 } & 240 & 580 & 140 & 960 \\
\hline \multirow{2}{*}{ Female } & $54,54 \%$ & $63,04 \%$ & $51,85 \%$ & $58,90 \%$ \\
\hline \multirow{2}{*}{ Male } & 200 & 340 & 130 & 670 \\
\hline \multirow{2}{*}{ All } & $45,46 \%$ & $36,96 \%$ & $48,15 \%$ & $41,10 \%$ \\
\cline { 2 - 5 } & 440 & 920 & 270 & 1630 \\
\hline
\end{tabular}

Notes: SC-PROF R denotes the maturity of the professional project among students. This variable divides students into 3 categories: PS: Students with a structured project, PP: Students who do not have professional project and PC: students whose career plan is being developed. 
The formulated projects consist of the following: $11.04 \%$ want to become an entrepreneur, $11.04 \%$ expressed their desire to have a job in the private sector, $5.52 \%$ would like to work in the public sector and $46.62 \%$ project to continue their studies until the Master's Degree or the Doctorate. We also find out that $25.76 \%$ are still undecided. The majority of girl students whose career plan is structured (240) want to continue their studies beyond the Master while male students whose professional project appears structured (200) are oriented towards both long studies and entrepreneurship. Thus, despite the initial imbalance, the number of boys (40) who consider working as an entrepreneur is equivalent to that of girls (50). It appears in general that when the professional project is not structured, students both girls and boys will indicate that they are either undecided or attracted to accomplish further studies. Finally, we note that the Pearson's Chi-squared $(x=31.42$, df $=17)$ revealed that these three variables, i.e. gender, maturation of the project and career choice are related (at the 5\% significance level).

From the identification of the projects, we define four sub-groups of students in our analysis: students considering an entrepreneurial career (EN), students who wish to pursue further studies in higher education (ET), students who prefer a paid professional career (S) and finally undecided students (IN).

\subsection{The role of volitional self-regulation skills}

Referring to hypothesis H1, the comparison between the levels of volitional self-regulation skills of the students based on the four types of project output reveals a lack of statistically significant differences. However, as shown in Chart 1, some variations appear when performing a more detailed comparison by using the planned comparisons of statistical posthoc. Thus, there are significant differences between students who long for having a job (S) and those considering an entrepreneurial career (EN) or between students who wish to continue their studies until the Master's Degree and Ph.D. (ET) and those who want to embrace the entrepreneurial career (EN). The following chart summarizes these observations.



EN = Entrepreneur, ST = Further studies IN = Undecided, $\mathrm{S}=$ Paid Employment.

The level of self-determination for students who wish to become entrepreneurs (mean $=3.4$ ) is higher than for students who want regular occupation (mean = 2.8). In other words, the students who wish to become entrepreneurs do it because entrepreneurship is more adapted to 
their personal aspirations than paid profession. He or she has a strategy to achieve his or her objective and it focuses on his or her entire attention and emotions.

Figure 2: Difference in level of self-motivation based on the project type

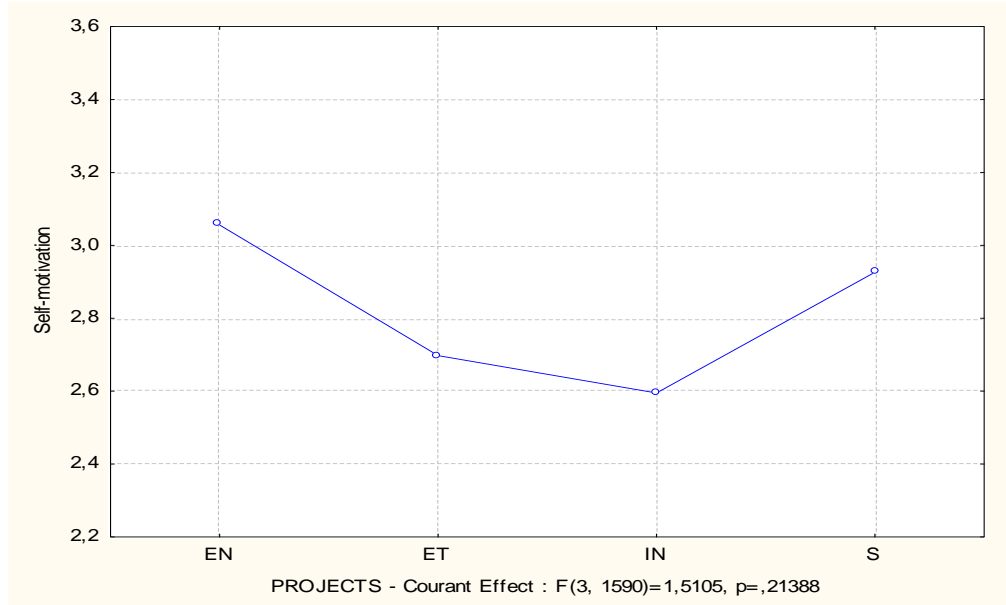

EN = Entrepreneur, $\mathrm{ST}=$ Further studies IN = Undecided, $\mathrm{S}=$ Paid Employment.

Regarding the proficiency in volitional self-motivation, our results show a slight difference distinguishing students who are considering an entrepreneurial career. In fact, students who wish to pursue an entrepreneurial activity (mean $=3.05$ ) have a high level of self-motivation compared to students who are undecided (mean $=2.59$ ) or those who are considering a longer academic path (mean $=2.92$ ). In other words, students who have an entrepreneurial project in the short term know how to maintain, without external interference, a motivation level that is high enough to act according to their objectives, as opposed to those who envisage looking for a job.

The difference in the level of resistance to the uncertainty about the future (Figure 3) shows a statistically significant difference between students who want to shift to an entrepreneurial career and those who wish to continue their studies (respectively Avg = 6.49 and Avg = 5.66; $\mathrm{F}=2.3, \mathrm{p}=.048)$. There is also a slight difference between the students who are considering an entrepreneurial career and those seeking work (respectively Avg = 6.49 and Avg =6.20). That is to say, students who wish to become entrepreneurs consider their future with greater confidence than others. 
Figure 3: Difference in level of resistance to the uncertainty about the future according to the project type

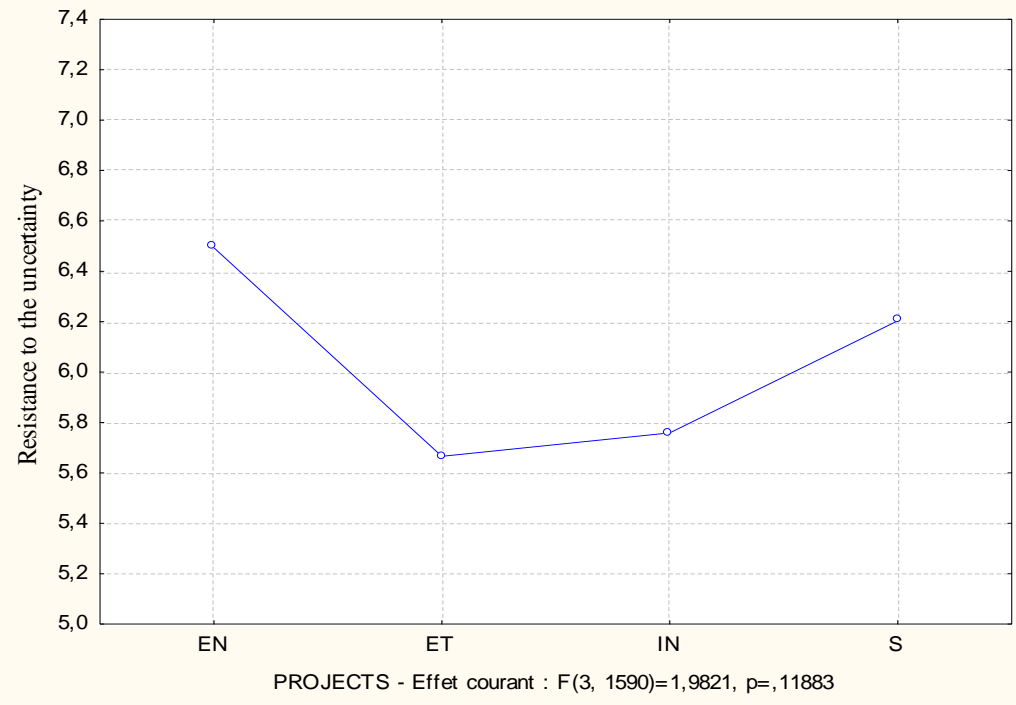

EN = Entrepreneur, $\mathrm{ST}=$ Further studies IN = Undecided, $\mathrm{S}=$ Paid Employment.

\subsection{Interaction between opinions and volitional skills}

Opinions on entrepreneurs and their professions are not crucial predictors per se of the entrepreneurial intention. However, when opinions concerning 1) the opportunistic behavior and 2) the commitment and skills of the entrepreneur are interacting respectively with 1) initiative and 2) determination, it seems championing the development of entrepreneurial intentions among students.

Indeed, the perception of the entrepreneur as "opportunistic" hinders the development of entrepreneurial intention and seems to act as an inhibitor $(\beta=-2.52, p=.002)$, until it is associated with a proactive personality. Entrepreneurship then becomes perceived as a concrete professional alternative $(\beta=.49, \mathrm{p}=.0083)$.

The opinion on entrepreneurs' commitment and skills is not likely to be decisive for an entrepreneurial career choice unless people are able to act with self-determination $(\beta=.52, \mathrm{p}$ $=.0073$ ). Moreover, the concept of the entrepreneur further "sacrificing" himself reinforces the desire to pursue studies rather than going to work, especially among students who seem attracted by entrepreneurship. They are basically different in their efforts to realize their entrepreneurial project, except in cases of students having a strong resistance to the idea of uncertainty about the future, namely through control of stress levels, inner tension, and anxiety, or if studying is not likely to be a desired alternative $(\beta=.24, p=.02)$. These observations are consistent with the hypothesis $\mathrm{H} 2$.

\section{DISCUSSION}

This research aims to bring about the psychosocial characteristics that contribute to a better understanding of the process of an entrepreneurial career choice. We focused our attention on the role of volitional skills in vocational orientation. The intention has been considered as a preceding feature of a career choice and a factor of influence and determination during the moments of transition from the shaping of choices to the implementation of concrete activities. 
The fact that a significant proportion of students who are enrolled at the university have no professional project and show indecision about the future is once again verified here (RossiNeves and Rousset, 2010). The economic crisis which has affected all countries since the summer of 2007, accounts for the increase in this phenomenon. Multiple relocations and several immediate measures like offshoring, reforms, job losses, etc., do not predict a better future for students. Students are particularly concerned about their professional future because they focus on dependent work as opposed to those who see their future career in the field of entrepreneurship. Unlike the dependent work, there is no incentive bonus to entrepreneurial work. Therefore, commitment to entrepreneurial activity is self-determined. The individual makes his or her choice to become an entrepreneur in spite of some inevitable obstacles and possible economic and environmental constraints. This commitment indicates personal dispositions such as self-motivation and the necessary skills to persevere in the entrepreneurial process, particularly because it presents pitfalls that are likely to affect the level of one's commitment to entrepreneurial activity.

Specifically, we sought to highlight the role of volitional skills in the conception of an intention to become an entrepreneur $(\mathrm{H} 2)$. Unlike what was demonstrated previously by some authors including Battistelli (2001), the viewpoints that people have on the entrepreneur and entrepreneurship, mainly positive opportunism, high skill, risk and sacrifice do not exclusively contribute to the development of entrepreneurial intention. This is still the case even when the entrepreneur is considered a "benefactor" or "exploiter". However, opinions commonly shared on the entrepreneur as an "opportunistic", "competent", "committed" and "sacrificing" do influence the development of entrepreneurial intention when they are matched to skills such as having initiative, self-determination and resistance to the uncertainty about the future. Such opinions as "opportunistic" and "sacrificing" are loaded with negative connotations that may justify the reluctance of people to privilege these businesses. The introduction of volitional competencies in this context is accounted for by the fact that they seem to determine the level of one's commitment to achieve a difficult goal.

More over, this is particularly true, as the individuals who are reluctant vis-à-vis the entrepreneur profession must demonstrate some resistance against the uncertainty about the future through their self-motivation, self-determination and initiative so as to overcome their fears and worries. Considering the theoretical propositions of Gollwitzer (1993) that the mechanisms of volition occur when the individual undertakes the achievement of his or her objective, our results rather argue that certain significant skills like self-determination, initiative and resistance to the uncertainty about the future are required in defining the objective to be pursued, according to its level of difficulty. These results show that the commitment to the profession of entrepreneur is considered as long, complicated, loaded with obstacles, difficult to achieve, and requires the volitional individual skills (H1) that will enable the person to protect his or her goal from distractors, to persevere and to optimize the plausibility of achieving it.

\section{Conclusion}

Psychological research in entrepreneurship intends to clarify the psychological characteristics in an entrepreneurial career through volitional competence and it is just beginning. In this respect, the results presented here must therefore be considered with caution. The originality of this work is to have introduced these skills in explaining the entrepreneurial intention. If the entrepreneurial choice is, actually, an objective that is pursued by a person's will, it should pertain to the personal factors rather than economic and environmental constraints. 
The dynamic approach adopted in this work to study the psychosocial processes involved in the definition of an entrepreneurial career helps understand the interest of young people in the entrepreneurial process. This research has demonstrated that volition has a key role in binding an individual commitment to an ambitious career objective.

This is a first step in this direction that may lay the foundations for a variety of future research perspectives. The first perspective could relate to the relationship between the process of defining a career and the skills of an individual. It is not only a matter of essential know-how, expertise or simple knowledge as a sufficient condition for a career choice but also the interaction between these structures and volitional competencies. The actors of vocational orientation have to take into account the psychological processes involved in making career decisions and to prepare their beneficiaries to the strategies leading them to the goal. The second perspective relates to checking these results on a larger sample of students including those who are already decided to set up on a business project.

\section{References}

Ajzen, I. (2002). Perceveid behavioral control, self-efficacy, locus of control, and the theory of planned behavior. Journal of Applied Social Psychology, 32(4), 665-683.

Ajzen, I., \& Fishbein, M. (1975). Belief, attitude, intention and behavior: an introduction to theory and research. Addison-Wesley, p.480.

Ajzen, I., \& Fishbein, M. (1980). Understanding attitudes and predicting social behavior. Englewood Cliffs, NJ: Prentice-Hall.

Ajzen, I., \& Madden, T. J. (1986). Prediction of goal directed behavior: Attitudes, intentions, and perceived behavioral control. Journal of Experimental Social Psychology, 22, 453-474.

Ashby, J. D., Wall, H., \& Osipow, S. H. (1966). Vocational certainty and indecision in college freshmen. Personnel and Guidance Journal, 44, 1037-1041.

Bagozzi, R. P., Baumgartner, H., \& Yi, Y. (1992). Appraisal processes in the enactment of intentions to use coupons. Psychology and Marketing, 9, 469-486.

Battistelli, A, (2001). I giovani e la scelta imprenditoriale. Milano: Angelo Guerini e associati.

Battistelli, A. (2006). The role of values, beliefs, and motivation on entrepreneurial intention. ICAP- $26^{\text {th }}$ International Congress of Applied Psychology -Athens, Greece July 16-21.

Battistelli, A., Atzeri, I., \& Fadda, L. (2003). Il ruolo delle intenzioni nella scelta professionale. Risorsa Uomo :Rivista di Psicologia del Lavoro e dell'Organizzazione, 9 (3/4).

Battistelli, A., \& Nyock I. S. (2008). La validation expérimentale du modèle de la congruence objective des valeurs sur le choix du métier d'entrepreneur. In: N. Pettersen, J.B. Boudrias, \& A. Savoie (Eds), Entre tradition et innovation, comment transformons-nous l'univers du travail ? Actes du 15ème Congrès International de Psychologie du Travail et des Organisations, Québec, Presses de l’Université de Québec.

Beckmann J., and Kuhl, J. (1985). Action control: From cognition to behavior. Berlin: pringer-Verlag. 
Boissin, J-P., Branchet B., Emin S., Herbert J.I. (2009). Students and Entrepreneurship: A comparative study France - United States, Journal of Small Business Entreprise, 22(2), 101122.

Boyd, N.G., \& Vozikis, G.S. (1994). The influence of self-efficacy on the development of entrepreneurial intentions and actions. Entrepreneurship Theory and Practice, 18(4), 63-77.

Branchet B., Augier B., Boissin J-P., \& Quere B., (2011). Strategic governmental economic activities in support of young French SMEs. Journal of Small Business and Enterprise Development, 18 (2), $384-402$.

Broonen, J.P. (2007). Le passé et l'avenir du concept de volition pour la psychologie de l'éducation et de la formation. Les cahiers internationaux de psychologie sociale, 74, 3-17.

Broonen, J.P. (2010). Des intentions aux actes: la volition en conseil en orientation. L'Orientation Scolaire et Professionnelle, 39(1), 137-171.

Campbell, R.E, \& Cellini, J.V. (1981). A diagnostic taxonomy of adult career problems. Journal of vocational behavior, 19, 175-190.

Charpentier, J., Collin, B., \& Scheurer, E. (1993). De l'orientation au projet de l'élève. Paris : Hachette Education.

Crites, J.O. (1969). Vocational Psychology. New York: Mc Graw-Hill.

Corno, L. (2004). Introduction to the special issue work habits and work styles: Volition in education. Teachers College Record, 106, 1669-1694.

Corno, L., \& Kanfer, R. (1993). The role of volition in learning and performance. In L. Darling-Hammon (Ed.), Review of research in education. Washington, DC: American Educational Research Association.

Cromie, S. (2000). Assessing entrepreneurship inclinations : some approaches and empirical evidence. European Journal of Work and Organizational Psychology, 9(1), 7-30.

Emmons, R.A, and Ferrari, J.R. (1995). Methods of procrastination and their relation to selfcontrol and self-reinforcement: An exploratory study. Journal of Social Behavior and Personality, 10, 135-142.

Forner, Y. (1999). Epreuve de Décision Vocationnelle. Paris: Editions et Applications Psychologiques.

Forner, Y., \& Autret, K. (2000). Indécision et adaptation à l'université. L'Orientation Scolaire et Professionnelle, 29(3), 499-516.

Forstmeier, S., \& Rüddel, H. (2008). Measuring volitional competences: psychometric properties of a short form of the Volitional Components Questionnaire (VCQ) in a clinical sample. The Open Psychology Journal, 1, 66-77.

Fraccaroli, F., \& Vitali, F. (2001). Verso la scelta imprenditoriale ? il ruolo dei significati attributi al lavoro. In Battistelli, A. I giovani e la scelta imprenditoriale, Milano: Angelo Guerini e associati.

Fuhrmann, A., \& Kuhl, J (1998). Decomposing self-regulation and self-control: The volitional components checklist. In J. Heckhausen \& C. Dweck (Eds.), Life span perspectives on motivation and control. Mahwah, NJ: Erlbaum, 15-49.

Gasse, Y. (2008). Conditions et influences majeures dans l'intention et le choix entrepreneurial. In: N. Pettersen, J.B. Boudrias, \& A. Savoie (Eds), Entre tradition et innovation, comment transformons-nous l'univers du travail? Actes du 15ème Congrès 
International de Psychologie du Travail et des Organisations, Québec, Presses de l'Université de Québec.

Gollwitzer, P.M. (1993). Goal achievement: The role of intentions, European Review of Social Psychology, 4(1), 141-185.

Gollwitzer, P. M. (1996). The volitional benefits of planning. In P.M. Gollwitzer \& J.A. Bargh (Eds.), The psychology of action: Linking cognition and motivation to behavior. New York: Guilford, 287-312.

Gollwitzer, P.M., \& Heckhausen H.(1987). Thought contents and cognitive functioning in motivational versus volitional states of mind. Motivation and Emotion, 11, 101-120.

Hale, J.L.; Householder, B.J. \& Greene, K.L. (2003). The theory of reasoned action. In J.P. Dillard \& M. Pfau (Eds.), The persuasion handbook: Developments in theory and practice. Thousand Oaks, CA: Sage, 259-286.

Holland, J.L. (1973). Making vocational choices. New Jersey : Prentice-Hall.

Krueger. N. (1993). Impact of prior entrepreneurial exposure on perceptions of new venture feasibility and desirability. Entrepreneurship Theory and Practice, 18(1), 5-21.

Kuhl, J. (1982). The expectancy-value approach within the theory of social motivation. Elaborations, extensions, critics. In. N.T. Feather (Ed.), Expectations and actions: expectancy-value models in psychology. Hillsdale, N.J: Erlbaum, 125-160.

Kuhl, J. (1985). Volitional mediators of cognitive-behavior consistency: Self-regulatory processes and actions versus state orientation. In: J. Kuhl \& J. Beckmann (Eds.), Action control: From cognition to behavior. Heidelberg, New York: Springer- Verlag, 101-128.

Kuhl, J. (2000). The volitional basis of personality systems interaction theory: Applications in learning and treatment contexts. International Journal of Educational Research, 33, 665-703.

Lemoine, C., \& Nettersheim J. (2008). Représentations et attentes relatives à l'entrepreneuriat. In: N. Pettersen, J.B. Boudrias, \& A. Savoie (Eds), Entre tradition et innovation, comment transformons-nous l'univers du travail ? Actes du 15ème Congrès International de Psychologie du Travail et des Organisations, Québec, Presses de l'Université de Québec.

Liñán, F., \& Chen, Y-W. (2009). Development and cross-cultural application of a specific instrument to measure entrepreneurial intentions. Entrepreneurship Theory and Practice, 33 (3), 593-617.

Mele, A. R. (2000). Deciding to act. Philosophical Studies, 100(1), 81-108.

Moreau, R., \& Raveleau, B. (2006). Les trajectoires de l'intention entrepreneuriale. Revue internationale PME, 19(2), 102-131.

Odoardi, C. (2008). Le rôle de valeurs, opinions et motivations sur l'intention entrepreneuriale. In P. Salengros, N. Kridis, C. Lemoine, \& A. Balikjian (Eds). Valeurs du travail, normativité et recrutement. Paris, L'Harmattan.

Oettingen, G., Hönig, G., \& Gollwitzer, P.M. (2000). Effective self-regulation of goal attainment. International Journal of Educational Research, 33(7), 705-732.

Rossi-Neves, P., \& Rousset, F. (2010). L'entrée à l'université: un choix d'orientation sexué ? In S. Croity-Beltz, Y. Preteur, \& V. Rouyer (Eds), Genre et socialisation de l'enfance à l'âge adulte. Expliquer les différences penser l'égalité. Erès

Zhu, J. (2004). Locating volition. Consciousness and Cognition, 13(2), 302-322. 
